\title{
Erratum to: The Aviation Paradox: Why We Can 'Know' Jetliners But Not Reactors
}

\author{
John Downer ${ }^{1}$ (D)
}

Published online: 25 September 2017

(C) The Author(s) 2017. This article is an open access publication

\section{Erratum to: Minerva (2017) 55: 229-248 \\ DOI 10.1007/s11024-017-9322-4}

The original version of this article is published as open access. Unfortunately the copyright and license terms were not indicated correctly. a) For Creative Commons Attribution (CC BY) licensed articles: "The original article [DOI] may be re-used and distributed under the terms of the Creative Commons Attribution License which permits any use, distribution, and reproduction in any medium, provided the original author(s) and the source are credited. The copyright of the original article retains with the author(s)." The original article was corrected.

The online version of the original article can be found under doi:10.1007/s11024-017-9322-4.

John Downer

john.downer@Bristol.ac.uk

1 School of Sociology, Politics and International Studies (SPAIS), University of Bristol, 11 Priory Road, Bristol BS8 1TU, UK 